\title{
Cretaciclavulina gusici n. gen., n. sp. (?family Valvulinidae BERTHELIN, 1880), a new larger benthic foraminifer from the lower Campanian of Brač Island, Croatia
}

\author{
Felix Schlagintweit ${ }^{1}$ and Blanka Cvetko Tešović ${ }^{2}$ \\ ${ }^{1}$ Lerchenauerstr. 167, D-80935 München, Germany; (corresponding author: felix.schlagintweit@gmx.de) \\ 2University of Zagreb, Faculty of Science, Department of Geology, Horvatovac 102a, Zagreb, Croatia; (bcvetko@geol.pmf.hr)
}

doi: $10.4154 / g c .2016 .17$

Crossref Simiarity ched

\section{Article history:}

Manuscript received August 19, 2015

Revised manuscript accepted March 30, 2016

Available online June 1, 2016

Keywords: Benthic foraminifera, Wall structure,

Valvulinidae, Palaeotextulariidae, Upper

Cretaceous, Croatia

\begin{abstract}
The larger benthic foraminifera Cretaciclavulina gusici n. gen., n. sp. is described from the lower Campanian Pučišća Formation of the Island of Brač, Croatia. With its elongate test, trochospiral to uniserial coiling, simple chambers, paraporous wall structure, and areal aperture provided with a cribrate apertural plate, Cretaciclavulina is tentatively placed into the family Valvulinidae BERTHELIN, 1880. Besides Neobalkhania bignoti CHERCHI, RADOIČIĆ \& SCHROEDER, 1991, Fleuryana adriatica DE CASTRO, DROBNE \& GUŠIĆ, 1994, and Reticulinella fleuryi CVETKO, GUŠIĆ \& SCHROEDER, 1997, Cretaciclavulina gusici represents the fourth benthic foraminifera newly described from the Upper Cretaceous shallow-water carbonates of Brač Island.
\end{abstract}

\section{INTRODUCTION}

The Upper Cretaceous shallow-water limestones of the Periadriatic Region (Adriatic, Apenninic, and Apulian carbonate platforms) contain a rich fauna of large-sized benthic foraminifera, many of them with special biostratigraphic importance (e.g., TORRE, 1966; LUPERTO SINNI, 1976; DE CASTRO, 1974; CVETKO TEŠOVIĆ et al., 2001; KORBAR \& HUSINEC, 2003; VELIĆ, 2007; CHECCONI et al., 2008; FRIJIA et al., 2015). In the Croatian part of the Adriatic-Dinaridic carbonate platform, a shallow-water facies rich in benthic foraminifera known as the Pučišća Formation was originally described from the island of Brač (GUŠIĆ \& JELASKA, 1990). The island of Brač is situated along the central part of the Adriatic-Dinaridic Carbonate Platform (ADCP; cf. JENKYNS, 1991; GUŠIĆ \& JELASKA, 1990; PAMIĆ et al., 1998; JELASKA, 2002) or Adriatic Carbonate Platform (AdCP; cf. VLAHOVIĆ et al., 2005). During the Mesozoic, several long-lived isolated carbonate platforms existed in the Me- diterranean region (the former central Tethys; present-day periAdriatic area). The ADCP was the largest of these platforms with relatively well preserved, mainly shallow-marine successions occasionally interrupted by episodes of emersion or drowning.

From the Pučišća Formation of Brač Island, three benthic foraminifera have already been introduced from thin-section material: Neobalkhania bignoti CHERCHI, RADOIČIĆ \& SCHROEDER, 1991, Fleuryana adriatica DE CASTRO, DROBNE \& GUŠIĆ, 1994, and Reticulinella fleuryi CVETKO, GUŠIĆ \& SCHROEDER, 1997. Another new taxon is reported here is Cretaciclavulina gusici n. gen., n. sp.

\section{GEOLOGICAL SETTING}

\subsection{Lithostratigraphy}

On the Island of Brač, situated along the central part of the Croatian Adriatic coast (Fig. 1), an almost complete, relatively undis-

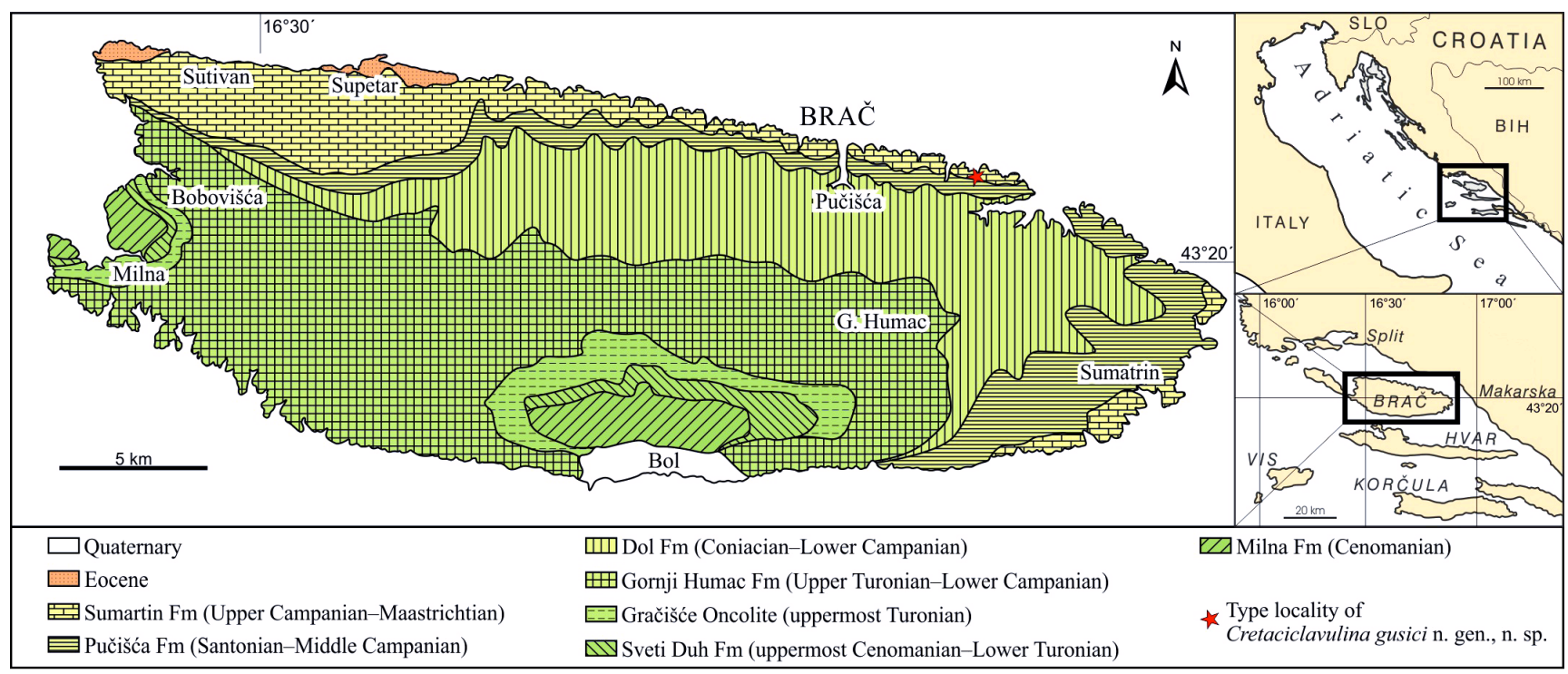

Figure 1. Map showing the location and geology of Brač Island, and type locality of Cretaciclavulina gusici n. gen., n. sp. (modified after GUŠIĆ \& JELASKA, 1990, CVETKO TEŠOVIĆ et al., 2001 and STEUBER et al., 2005). 


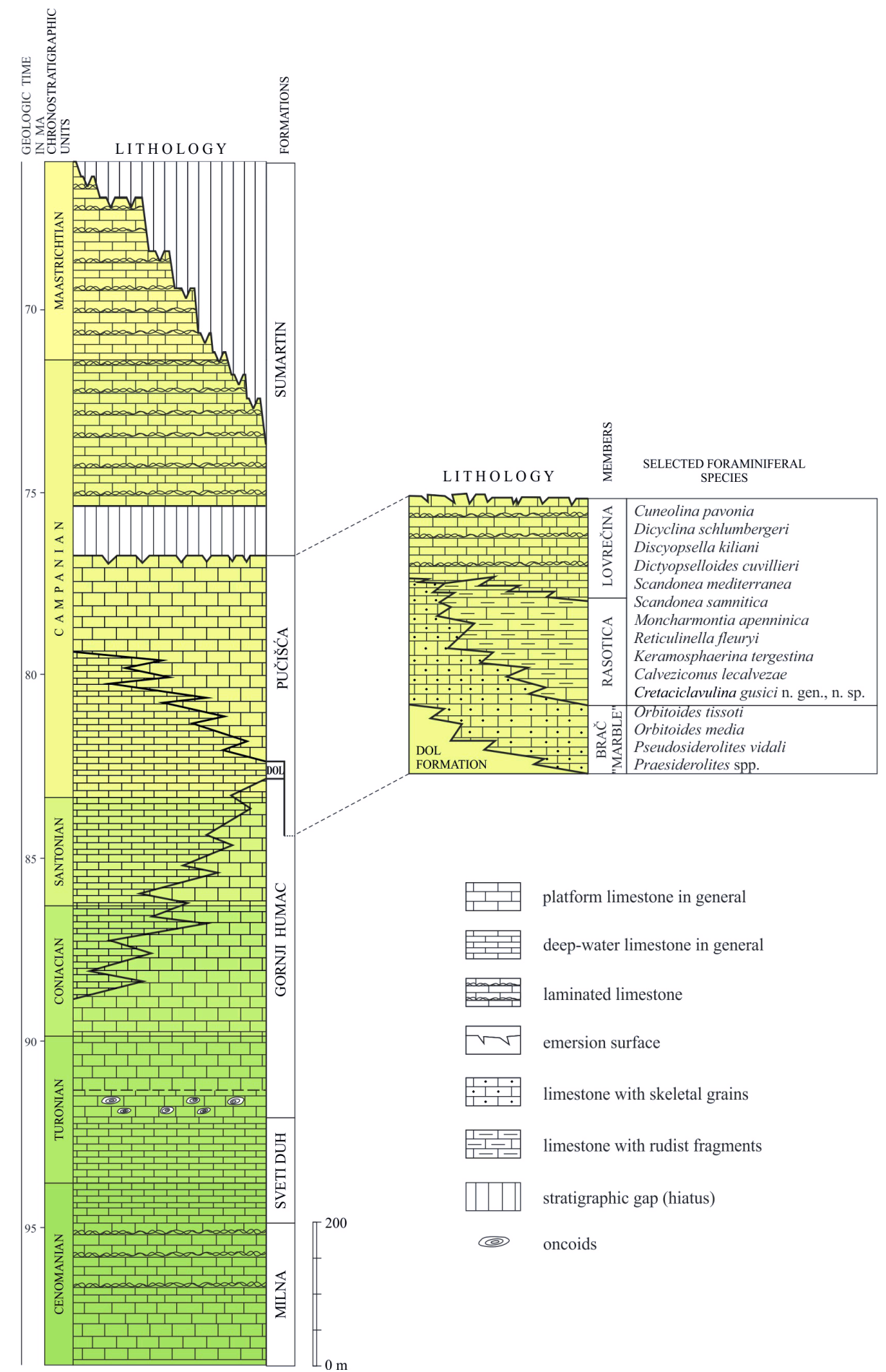

Figure 2. Stratigraphic synthesis of the Upper Cretaceous deposits of Brač Island with detailed lithology and selected foraminiferal assemblage of Pučišća Formation (adapted from GUŠIĆ \& JELASKA, 1990, CVETKO TEŠOVIĆ et al., 2001 and STEUBER et al., 2005).

turbed, and well-exposed Upper Cretaceous succession of the ADCP is exposed. This succession has served as a representative example for the Upper Cretaceous shallow-water carbonate development of the ADCP (Figs. 1, 2). Palaeogene deposits are also present along the northwestern and, as scattered outcrops, along the southeastern coast of the island (Fig. 1).

The Upper Cretaceous platform limestones represent a thick „layer-cake” sedimentary succession (up to $1500 \mathrm{~m}$ ), consisting predominantly of small-scale shallowing-upward cycles (GUŠIĆ \& JELASKA, 1990). The succession has been subdivided into six lithostratigraphic units (PEJOVIĆ \& RADOIČIĆ, 1987; GU-
ŠIĆ \& JELASKA, 1990), ranging in age from Cenomanian to Maastrichtian (Fig. 2):

- The Milna Formation (Cenomanian) comprises bioclastic (including foraminifera, rudists and other mollusca) wackestones to grainstones alternate with microbial laminites, occasional slump features, and rare intraformational breccias (GUŠIĆ \& JELASKA, 1990; KORBAR et al., 2012).

- The Sveti Duh Formation (uppermost Cenomanian-Lower Turonian) comprises pelagic skeletal wackestones with planktonic foraminifera and calcispheres indicate drown- 
ing of the ADCP (JENKYNS, 1991; GUŠIĆ \& JELASKA, 1990; DAVEY \& JENKYNS, 1999; KORBAR et al., 2012).

- The Gornji Humac Formation (Upper Turonian-Lower Campanian) comprises oncoid-bearing beds in the lower part (e.g. the „Gračišće Oncolite” Member) during the Late Turonian-Early Coniacian, which cap the underlying pelagic deposits and evidence a shallowing and reinstallation of carbonate platform environments, which were gradually less restrictive and more favourable for populations of shallow-water benthic organisms.

- The Dol Formation (Coniacian-Lower Campanian) comprises micrites with abundant calcispheres and planktonic foraminifera indicating a second Late Cretaceous pelagic episode.

- The Pučišća Formation (Santonian-Middle Campanian): platform sediments with rudists in parautochthonous position and shallow-water bioclastic limestones indicate the gradual infilling of the intraplatform trough, known as the Brač „Marble” Member. With the progradation of the platform, the protected back-margin environments gradually occupied larger areas until they completely overlaid the Brač „Marble” Member. These environments are represented by the two superpositional-lateral subunits of the Rasotica member (rudist biostromes, bioclastic floatstones to rudstones and foraminiferal wackestones/packstones with rich and diverse assemblages of larger benthic imperforate foraminifera) and the Lovrečina member (uppermost member characterized by regularly developed shallowingupward sequences with features indicating emergence conditions with subaerial erosion at the top, probably reflecting a global drop of sea level in the Middle to Late Campanian).

- The Sumartin Formation (Upper Campanian-Maastrichtian) represents the regressive cycles of the Maastrichtian, above the Late Campanian emersion, which were deposited in peritidal environments.

The new benthic foraminifer described in the present paper was observed in the Campanian deposits of the uppermost part of the Gornji Humac and are more frequent in the Pučišća Formation (Rasotica and Lovrečina members).

\subsection{Biostratigraphy}

PEJOVIĆ \& RADOIČIĆ (1987) subdivided the Upper Cretaceous deposits into six formations mainly based on benthic foraminifera and rudists. Six formations were also recognized by GUŠIĆ \& JELASKA (1990), but their litho- and chronostratigraphic interpretation differs from that of PEJOVIĆ \& RADOIČIĆ (1987). They emphasized the diachronous character of some formation boundaries (Fig. 2) and subdivided some of them into smaller units. Rudist bivalves and benthic microfossils have been studied comprehensively as biostratigraphic markers for the upper Cretaceous succession of Brač (POLŠAK et al., 1982; GUŠIĆ \& JELASKA, 1990; CVETKO TEŠOVIĆ et al., 2001, KORBAR, 2003; STEUBER et al., 2005 and references therein) and the type localities of several taxa are located on the island.

The Pučišća Formation contains especially rich assemblages of larger benthic foraminifera dominated by various imperforate taxa in the Rasotica and Lovrečina members and hyaline foraminifera in the Brač „Marble” Member. These assemblages were used for the interpretation of stratigraphic and palaeoenvironmental features (GUŠIĆ \& JELASKA, 1990; CVETKO TEŠOVIĆ et al., 2001). CVETKO TEŠOVIĆ et al. (2001) described these assemblages in detail including taxonomic, phylogenetic, stratigraphic and palaeoecologic aspects. The Late (but not latest) Campanian age of the Pučišća Formation is largely based on the age determination of the Brač „Marble” Member. GUŠIĆ \& JELASKA (1990) gave stratigraphic priority to the relevant and well-studied larger benthic foraminifera (orbitoidids and siderolitids). Based on numeric ages derived from strontium-isotope stratigraphy (SIS) of low-Mg calcite of rudist shells, STEUBER et al. (2005) revised the chronostratigraphy of the ConiacianMaastrichtian platform carbonates of the island of Brač. According to the strontium-isotope stratigraphy, the Pučišća Formation is mid-Santonian to late Middle Campanian in age. Based on benthic foraminifera, especially Calveziconus lecalvezae CAUS \& CORNELLA, the samples containing Cretaciclavulina gusici n. gen. n. sp. can be assigned to the lower Campanian (see revised ranges of FRIJIA et al., 2015).

\section{MATERIAL AND REPOSITORY}

The micropalaeontological analysis of samples from the Pučišća Formation was performed on about 200 thin sections. Sections of Cretaciclavulina gusici n. gen, n. sp. were only observed in 15 of them. The investigated samples are the property of the Croatian Geological Survey and their repository (inventory numbers: 10807-10815) is currently in the Geological-Palaeontological Department of the Croatian Natural History Museum, Demetrova 1, Zagreb, Croatia.

\section{MICROPALAEONTOLOGY}

\subsection{Description of the new taxon}

Phylum: Foraminifera D'ORBIGNY, 1826

Class: Globothalamea PAWLOWSKI et al., 2013

Order: Ataxophragmiina FURSENKO, 1958

Superfamily: Textulariacea EHRENBERG, 1838

Family:?Valvulinidae BERTHELIN, 1880

Remarks: With its elongate test, trochospiral later becoming uniserial, the simple chambers, a paraporous wall structure, and probable cribrate apertural plate, Cretaciclavulina is tentatively placed into the family Valvulinidae BERTHELIN, 1880. According to LOEBLICH \& TAPPAN (1987, p. 181), the Valvulinidae range in age from the Palaeocene to the Holocene.

\section{Cretaciclavulina n. gen.}

Type species: Cretaciclavulina gusici n. gen., n. sp.

Origin of the name: Composite name referring to the Cretaceous and the genus Clavulina D'ORBIGNY.

Diagnosis: Test elongate, trochospiral (most likely triserial) to uniserial, with a short intermediate biserial stage between these. Chambers simple, broad low, enlarging in the triserial stage and of nearly constant width in the uniserial stage. Wall thick agglutinating, and canaliculate (paraporous), possibly with an inner calcareous (?aragonitic) layer. Foramen single interiomarginal in the trochospiral and areal in the uniserial part. Aperture areal, provided with a cribrate apertural plate.

Remarks: The wall structure combined with the elongate test and its trochospiral to uniserial chamber arrangement allow a comparison of Cretaciclavulina with some representatives of the family Palaeotextulariidae GALLOWAY, 1933, Valvulinidae BERTHELIN, 1880, and partly also the Ataxophragmiidae SCHWAGER, 1877, Verneuilinidae CUSHMAN, 1911 as well as Pseudogaudryinidae LOEBLICH \& TAPPAN, 1985 (Fig. 3A).

The wall of Cretaciclavulina displays closely spaced, fine and more or less parallel, more rarely bifurcating canaliculi or parapores that are not open to the exterior, but end blindly shortly 


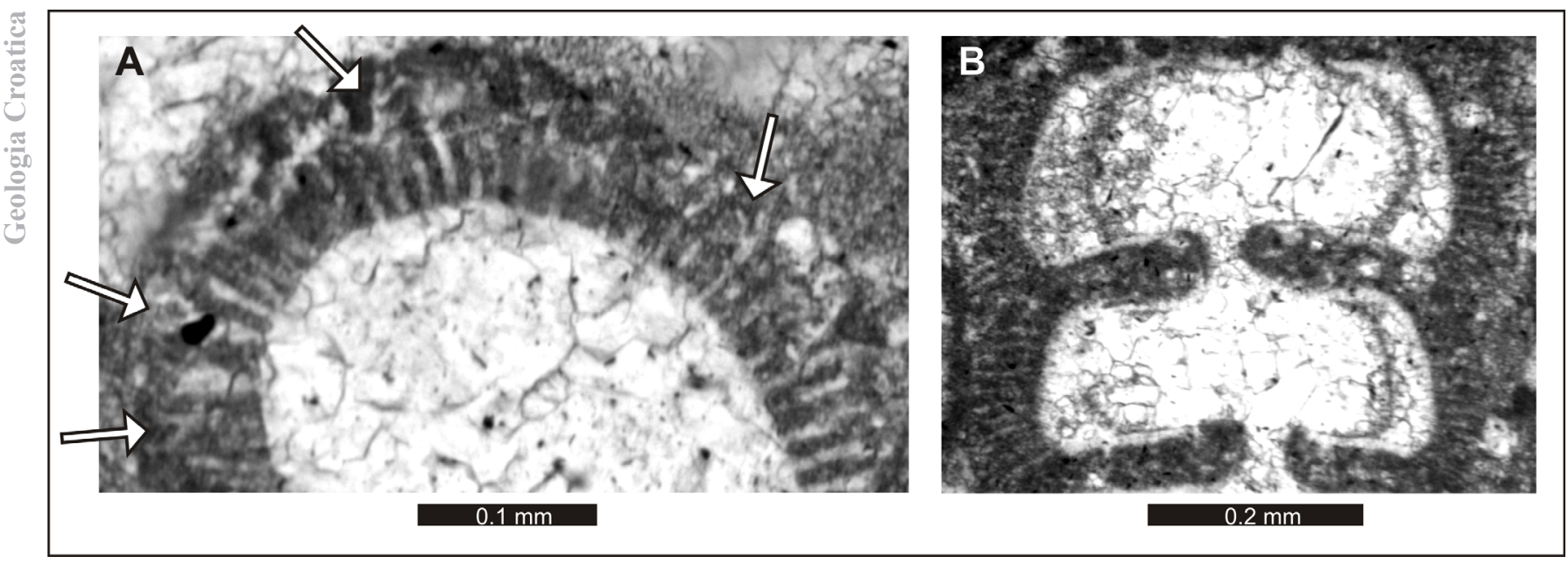

Figure 3. Details of the wall structure of Cretaciclavulina gusici n. gen., n. sp. A) Detail from PI. 1D showing rare distal pore bifurcations (arrows). Thin-section S2N124. B) Detail from the holotype specimen of PI. 1A showing the inner recrystallized calcareous layer. Thin-section 514 K3V71/5.

before the outer test surface (see BANNER et al., 1991; HOTTINGER et al., 1990; HOTTINGER, 2006, for details) (Fig. 3A). This thin outer ,pavement" is commonly eroded. Canaliculi appear scarcer to absent in the septa. The phylogentic relationship concerned with the appearance of such ,false keriothecae" (VACHARD et al., 2004) is still poorly understood and requires further study (see also RIGAUD et al., 2015).

In the adult chambers of some Cretaciclavulina the outline of an inner calcareous layer, morphologically close to that of the Palaeotextulariidae (Fig. 3B), is preserved. In Palaeotextulariidae, however, the inner layer is clearly yellowish and fibrous whereas
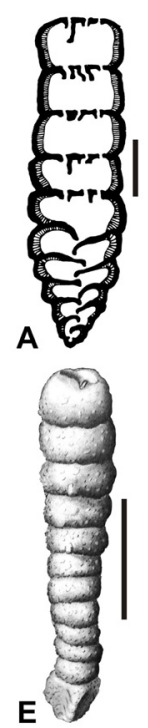
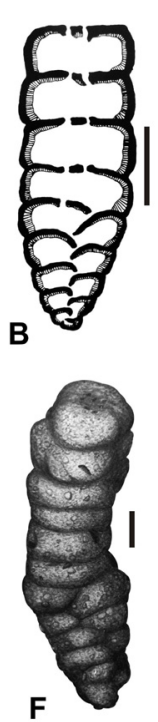

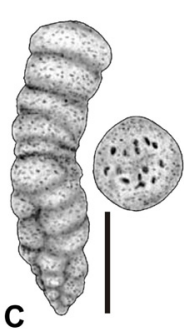

C

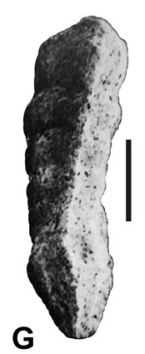

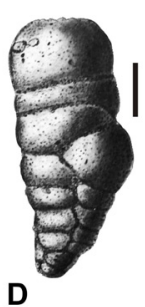

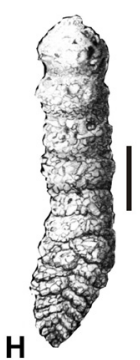

Figure 4. Foraminiferal genera that are compared with Cretaciclavulina n. gen. A) Climacammina antiqua (BRADY), early Carboniferous of Scotland (from LOEBLICH \& TAPPAN, 1987, pl. 228, fig. 11). B) Deckerella clavata CUSHMAN \& WATERS, late Carboniferous of Texas (from LOEBLICH \& TAPPAN, 1987, pl. 229, fig. 3). ) Gerochella cylindrica NEAGU, Valanginian of Romania (from NEAGU, 1997, Fig. 1/40-41). D) Goesella rotundata (CUSHMAN), Holocene of Philippine Islands (from LOEBLICH \& TAPPAN, 1987, pl. 200, fig. 6). E) Clavulina parisiensis d'ORBIGNY, Middle Eocene of France (from LOEBLICH \& TAPPAN, 1987, pl. 200, fig. 3). F) Cribrogoesella robusta (BRADY), Holocene of Pernambuco, Atlantic (from LOEBLICH \& TAPPAN, 1987, pl. 201, fig. 3), G) Clavulinopsis hofkeri BANNER \& DESAI, Upper Cretaceous (Campanian) of Texas, USA (from LOEBLICH \& TAPPAN, 1987, pl. 196, fig. 3). H) Bigenerina nodosaria D'ORBIGNY, Holocene of France (from LOEBLICH \& TAPPAN, 1987, pl. 191, fig. 1). Scale bars $=0.3 \mathrm{~mm}$. that observed in Cretaciclavulina is recrystallized into sparite (?originally aragonitic). It is worth mentioning here that a yellowish inner fibrous calcitic layer was reported recently from the Upper Cretaceous (Coniacian) genus Siphodinarella (SCHLAGINTWEIT et al., 2014). Axial sections (that usually do not allow biserial to be distinguished from the triserial forms) of Cretaciclavulina show morphological resemblance to large-sized palaeozoic Palaeotextulariid genera such as Climacammina BRADY (Fig. 4A), Deckerella CUSHMAN \& WATERS (Fig. 4B), and Palaeobiginerina GALLOWAY. These taxa are biserial becoming uniserial in the adult part. The wall structure is originally described as ,calcareous, microgranular, commonly with an inner radial fibrous layer" (LOEBLICH \& TAPPAN, 1987, p. 218). This view was corrected by PILLER (1990) evidencing the agglutinating character of the outer layer.

The uniserial stage in Cretaciclavulina does not abruptly follow the trochospiral (triserial) stage, but with a mediating short biserial stage. Examples of such triserial-biserial-uniserial tests are for example the agglutinated Lower Cretaceous Spiroplectinata CUSHMAN, 1927 of the Verneuilinidae (TYSZKA \& THIES, 2001; KAMINSKI et al., 2011) and Gerochella NEAGU, 1997 (Fig. 4C) of the Ataxophragmiidae, the Eocene to Holocene Goesella CUSHMAN, 1933 of the Valvulinidae (Fig. 4D), as well as the Late Cretaceous (Campanian) Rectogerochammina KAMINSKI, CETEAN \& NEAGU, 2010 of the family Prolixoplectidae LOEBLICH \& TAPPAN, 1985. The four mentioned genera exhibit a solid (non-canaliculate) wall different from that of $\mathrm{Cre}$ taciclavulina.

Forms with a serial and later uniserial test as well as a canaliculate wall structure are reported from the various representatives of the family Valvulinidae BERTHELIN, with the genera Clavulina D'ORBIGNY, 1826, Cribrogoesella CUSHMAN, 1935, and Gyrovalvulina LOEBLICH \& TAPPAN, 1985 as well as of the family Pseudogaudryinidae LOEBLICH \& TAPPAN, 1985, with the genera Clavulinopsis BANNER \& DESAI, 1985, and Pseudoclavulina CUSHMAN, 1936. The differences between these genera and Cretaciclavulina can be roughly summarized as follows (only the main differences are stressed; ages and generic features acc. to LOEBLICH \& TAPPAN, 1987):

- Clavulina D’ORBIGNY, 1826 (Palaeocene to Holocene) (Fig. 4E): triangular early and uniserial adult stage (3-1 chamber arrangement opposed to 3-2-1 in Cretaciclavu- 
lina; see also the comparative table in WEIDICH, 1988); finely bifurcating pores are sealed internally by an organic lining (that may simply not be preserved in Cretaciclavulina?); aperture with an imperforate toothplate; toothplates of successive chambers oriented 120 degrees apart.

- Cribrogoesella CUSHMAN, 1935 (Miocene to Holocene) (Fig. 4F): early trochospiral stage with up to five chambers; rapidly reducing to three, then biserial and finally uniserial; both lateral walls and septa strongly canaliculate; aperture cribrate in the uniserial stage (opposed to single, and areal in Cretaciclavulina).

- Gyrovalvulina LOEBLICH \& TAPPAN, 1985 (Eocene): ,triserial and triangular early stage and later chambers in a loose spiral, with progressively fewer chambers per whorl, until the final chamber nearly completely encircles the axis" (LOEBLICH \& TAPPAN, 1985, p. 213).

- Clavulinopsis BANNER \& DESAI, 1985 (Campanian to Maastrichtian) (Fig. 4G): test triangular (throughout!); early stage triserial, later abruptly becoming uniserial (3-1 chamber arrangement opposed to 3-2-1 in Cretaciclavulina).

- Pseudoclavulina CUSHMAN, 1936 (Upper Cretaceous to Lower Eocene): early stage triangular, then uniserial (3-1 chamber arrangement) thereby reducing abruptly test diameter; aperture terminal, but without a distinct tooth.

Last but not least, the genus Bigenerina D'ORBIGNY, 1826 (Eocene to Holocene acc. to LOEBLICH \& TAPPAN; 1987) shows an early biserial stage, later becoming abruptly uniserial, and an agglutinating, canaliculate wall (Fig. 4H).

It is worth mentioning here that the Mesozoic-Cenozoic taxa that were compared with Cretaciclavulina were all described from isolated specimens recovered from deeper water marly lithologies. Cretaciclavulina instead is reported from typical shallow-water platform carbonates.

\section{Cretaciclavulina gusici $\mathrm{n} . \mathbf{s p}$.}

Fig. 3, Pl. 1

1990 Unidentified or unknown foraminifera - GUŠIĆ \& JELSKA, pl. 15, figs. 8, 9 .

Origin of the name: Dedicated to Ivan Gušić (Zagreb) for his contributions to the taxonomy of benthic foraminifera. The new taxon was also illustrated for the first time by GUŠIĆ \& JELASKA (1990) (see synonymy).

Holotype: Subaxial section illustrated in Pl. 1, Fig. A, and details in Pl. 1, Fig. G, and Fig. 3B, thin-section inv. no. 10807 (514 K3V71/5).

Paratypes: Specimens illustrated in $\mathrm{Pl}$. 1, Figs. B-F, H-O (inv. no. 10808-10815).

Type-locality: On the east side of the Otočac cove (northeast coast of the Brač island). Approximate coordinates: $43.352294^{\circ} \mathrm{N}$, $16.796578^{\circ}$ (Fig. 1).

Type-level: Lower Campanian; the highest levels of the Gornji Humac Formation, (Upper Turonian-Lower Campanian), and the Rasotica and Lovrečina Members (Lower-Middle Campanian) in the Pučišća Formation) (Fig. 2).

Diagnosis: Being monospecific see diagnosis of genus.

Description: Test elongate, trochospiral to uniserial. The early stage, rounded triangular (with concave sides), is most likely triserial as visible in transverse sections (Pl. 1B) becoming increasingly rounded. In the specimen shown in Pl. 1A, this stage amounts about $\sim 40 \%$ of the total test. The rounded void at the

Table 1. Benthic foraminifera (selection) co-occurring with Cretaciclavulina gusici.

\begin{tabular}{|c|c|c|c|c|c|c|c|c|c|c|c|c|c|c|c|c|c|c|c|}
\hline Thin-sections & 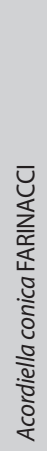 & 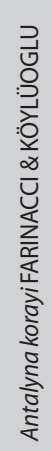 & 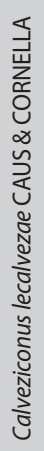 & 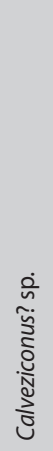 & 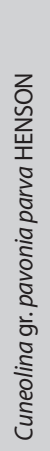 & 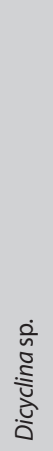 & 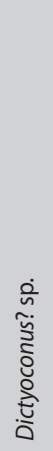 & 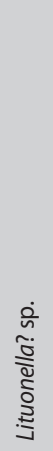 & 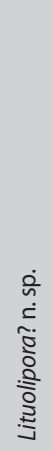 & $\frac{\underline{\underline{\underline{0}}}}{\frac{\underline{\underline{\underline{o}}}}{\bar{\varepsilon}}}$ & 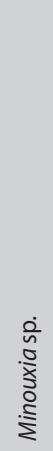 & 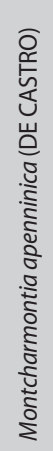 & 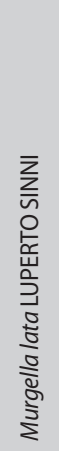 & 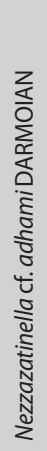 & 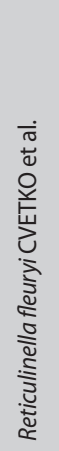 & 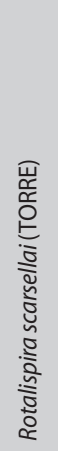 & 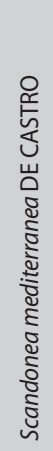 & 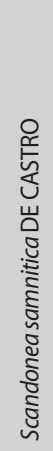 & 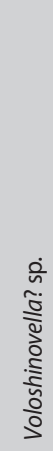 \\
\hline 514 K3V71/5 & & $x$ & $x$ & & $x$ & & & & & $x$ & & $x$ & & & & & & & \\
\hline $2511^{5} 18_{4}$ & & & $x$ & & $x$ & & & & & $\mathrm{X}$ & $x$ & $x$ & & & & & & & \\
\hline 208 18/1S4 & $x$ & $x$ & $x$ & $x$ & $x$ & $x$ & & $x$ & $x$ & $\mathrm{X}$ & $x$ & & & & & & $x$ & $x$ & \\
\hline $223^{187 / 1 ~ S 4}$ & $x$ & & $x$ & & $x$ & & & & & $x$ & $x$ & & & & $x$ & & & & \\
\hline $1 \mathrm{Kr} 1^{13} 15$ & $?$ & & $?$ & & & & & & & $x$ & $x$ & & $x$ & & & & & & \\
\hline S2N124 & & & & & $\mathrm{X}$ & $?$ & & & $x$ & $\mathrm{X}$ & & & & & & & & & \\
\hline 209 18/2S4 & & & $x$ & & $x$ & $x$ & & & $x$ & $x$ & & & & & & & & & \\
\hline 132 918 Ku3 & & & $x$ & & & $x$ & & & & $x$ & & $?$ & & & & & & & \\
\hline $21^{42}{ }_{13} 15 \mathrm{KR} 1$ & & & $x$ & & $x$ & & & & $x$ & $x$ & & & & & $x$ & & & & \\
\hline $212^{7}{ }_{2} 854$ & $x$ & & & & $x$ & $x$ & & & $x$ & $x$ & & $x$ & & & $x$ & $x$ & & & \\
\hline $528 \mathrm{~K} 213^{46} 15$ & & & & & & $x$ & & & & $x$ & $x$ & $x$ & & & & & & & \\
\hline Mu $3 \mathrm{~K} 606 / 20$ & $x$ & & $x$ & & $x$ & $x$ & $x$ & & & $x$ & $x$ & $x$ & $?$ & $x$ & & & & & $x$ \\
\hline
\end{tabular}




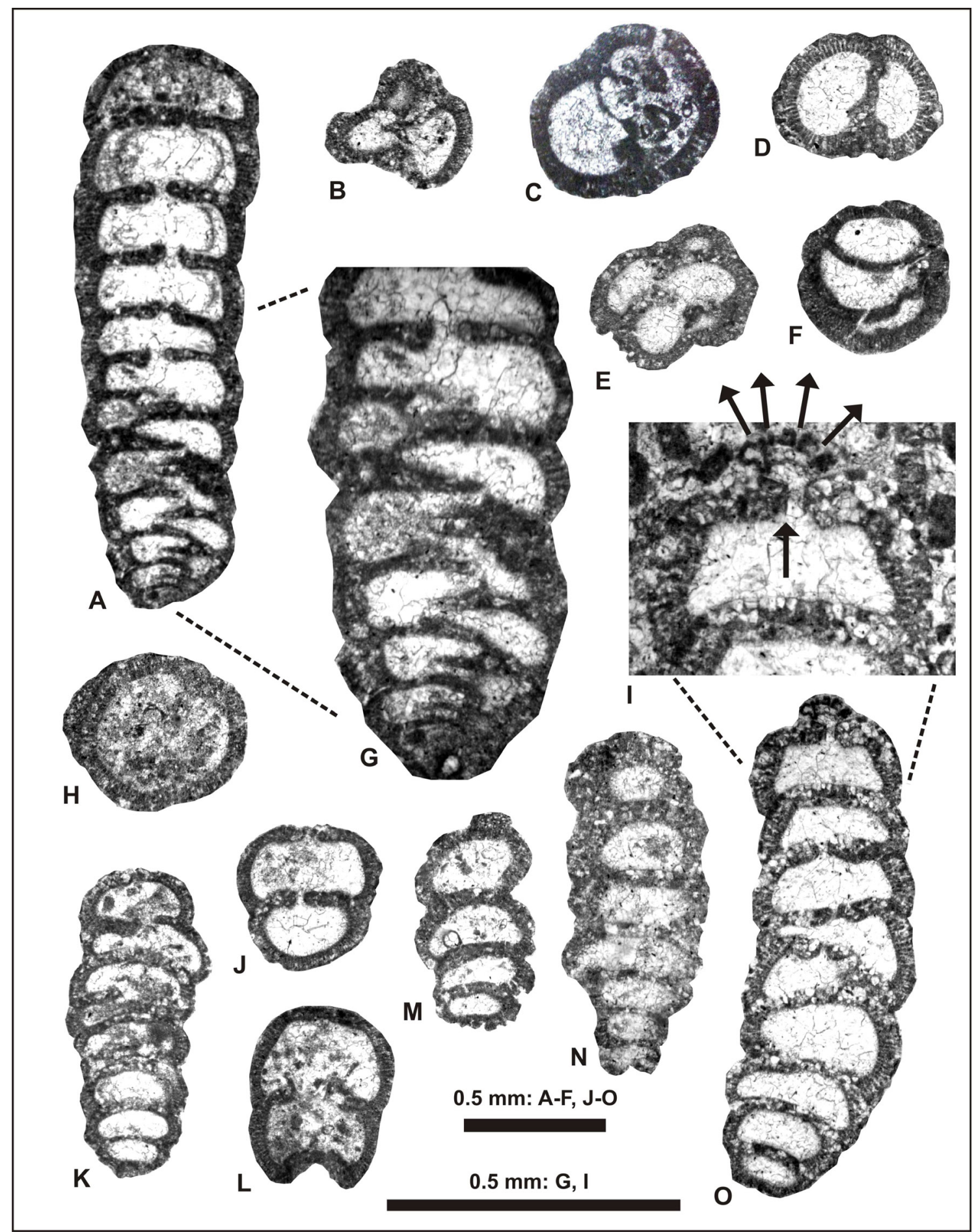

Plate 1. Cretaciclavulina gusici from the early Campanian of Brač Island.

A Subaxial section, holotype specimen. Thin-section inv. no. 10807 (514 K3V71/5).

B Slightly oblique transverse section showing triangular outline with concave sides, lower part of the triserial stage. Thin-section inv. no. 10808 ( $\left.2233^{18} 7 / 1 \mathrm{~S} 4\right)$.

C Slightly oblique transverse section in the upper part of the trochospiral stage (see GUŠIĆ \& JELASKA, 1990, PI. XV, Fig. 9). Thin-section inv. no. 10809 (213 ${ }_{2}{ }_{2} 18 / 2$ S4).

D Slightly oblique section of the biserial stage. Thin-section inv. no. 10810 (S2N124).

E Oblique section of the triserial stage. Thin-section inv. no. 10811 (132, $18{ }_{4}$ Ku3).

F Oblique section of the trochospiral stage. Thin-section inv. no. 10812 (209 18/2S4).

G Detail from A, showing the transition of the triserial to the uniserial stage. Note the pseudo-keriothekal wall structure. Thin-section inv. no. 10807 (514 K3V71/5).

H Slightly oblique transverse section of the uniserial stage. Thin-section inv. no. 10807 (514 K3V71/5).

I Detail from O, showing the cribrate apertural plate. Thin-section inv. no. $10813\left({ }^{13} 15 / 1 \mathrm{Kr} 1\right)$.

J Oblique section of the uniserial stage cutting two chambers. Thin-section inv. no 10808 (223 187/1 S4).

K Subaxial section of a broken specimen cutting 8 chambers of the uniserial stage. Thin-section inv. no. 10808 ( $2233^{187 / 1 ~ S 4) . ~}$

L Broken fragment consisting of two chambers of the uniserial stage, axial section. Thin-section inv. no. 10814 (208 18/1S4).

M Oblique or tangential section of a broken specimen cutting 4 chambers of the uniserial stage. Thin-section inv. no. 10813 ( $\left.{ }^{13} 15 / 1 \mathrm{Kr} 1\right)$.

N Oblique section. Thin-section inv. no. $10815\left(21^{42}{ }_{13} 15 \mathrm{KR} 1\right)$.

o Longitudinal, non-centered section of the uniserial stage, notably 9 chambers, of a specimen. The apertural detail is shown in I. Thin-section inv. no. 10813 $\left({ }^{13} 15 / 1 \mathrm{Kr} 1\right)$. 
apex of the holotype specimen possibly refers to the proloculus (Fig. Pl. 1G). Altogether, the information on the initial stage is poor as most random sections are beyond the uniserial stage. Further towards the following uniserial stage, transverse sections of the test become more and more rounded in outline (Pl. 1B-E, G). A short biserial part occurs between the triserial and uniserial stages (Pl. 1D).

The adult stage is represented by a series of at least six uniserial chambers. This stage is roughly cylindrical, rectilinear to slightly bent, with chambers that only slightly increase in breadth and height. This accounts for the slender, sometimes slightly bent cylindroconical test morphology. Transverse sections are either circular or slightly elliptical in outline. The solid septa are almost planar (so that the chambers are not overlapping) and pierced by a single foramen in a central to slightly eccentric position. In axial sections, the appressed chambers have a low rectangular shape with rounded margins. Wall agglutinating, with a large amount of microgranular or microagglutinated calcareous material, thick and canaliculate (or paraporous) with fine pores (or canaliculi) ending blindly shortly before the outer test surface (Fig. 3A). This thin outer layer (or ,pavement”, see HOTTINGER, 2006) is mostly eroded. The pores are straight and more or less parallel (radial arrangement), but may branch in the outer part. In the adult uniserial chambers of the holotype specimen, remnants of an inner calcitic layer are discernible. The thickness of this layer is about $0.04 \mathrm{~mm}$ at the lateral walls and is decreasing/tapering upon the septa towards the foramina (Fig. 3B). Foramen single interiomarginal in the trochospiral and areal in the uniserial part. Aperture (last chamber) areal, provided with a cribrate apertural plate (Pl. 1I).

\section{Dimensions:}

Test length: up to $2 \mathrm{~mm}$

Test diameter: up to $0.7 \mathrm{~mm}$

Number of chambers last mm axial length: 5

Adult chamber height: $\sim 0.18$ to $\sim 0.2 \mathrm{~mm}$

Wall thickness (without calcitic inner layer): $\sim 0.065$ to $\sim 0.1 \mathrm{~mm}$

Diameter caniculi: $\sim 7 \mu \mathrm{m}$

Remarks: Cretaciclavulina gusici has been illustrated by GUŠIĆ \& JELASKA (1990, pl. 15, figs. 8, 9) as an ,unidentified or unknown foraminifera". The two illustrations presented are a longitudinal section of the uniserial final part cutting nine chambers (op. cit., pl. 15, fig. 8, refigured here on Pl. 1A, and detail in $\mathrm{G})$. The other one represents an oblique transverse section of the triserial early portion (op. cit. Pl. 15, fig. 9, refigured here on Pl. 1C). Based on these sections GUŠIĆ \& JELASKA (1990) summarized the characteristics of this taxon comprising ,, a well-developed keriothecal wall structure, in addition to a comparatively simple morphology and lack of endoskeleton". In fact, this material was insufficient for recognizing the new character of the form based on the combination of the different coiling modes in the early and late test portions.

Transverse sections of the chrysalidinid Praechrysalidina infracreatcea LUPERTO SINNI, 1979 (Aptian of south Italy) (e.g., LUPERTO SINNI, 1985, pl. 6, fig. 5-6) are very similar to those of Cretaciclavulina gusici. $P$. infracretacea differs from the latter mostly by having a triserially coiled test throughout. Moreover, the early part of the test with its foramina are said to be most likely simple with broad apertural flaps situated at the inner margin, later becoming pierced by numerous areal pores (cribrate) opposed to the single areal foramina in Cretaciclavulina (see also BANNER et al., 1991).
The species Gerochella cylindrica NEAGU (Lower Valanginian of Romania, Fig. 4C) can be considered homeomorphic to Cretaciclavulina gusici, but is more slender (test length up to $1.4 \mathrm{~mm}$; width between 0.24 to $0.29 \mathrm{~mm}$ ). As already remarked, the wall of $G$. cylindrical is compact, finely agglutinated, whereas in Cretaciclavulina the wall is canaliculate (paraporous).

Microfacies: Cretaciclavulina gusici has been observed in packstones and grainstones containing a diverse association of benthic foraminifera: cuneolinids, orbitolinids, soritids and other miliolids, nezzazatids, coxitids, spirocyclinids, nautiloculinids, textulariaceans, rare rotaliids and others (Tab. 1).

\section{ACKNOWLEDGMENT}

The authors appreciate the very helpful and constructive comments of the two reviewers Sylvain RIGAUD (Singapore) and Mike SIMMONS (Oxford). This work has been supported by the Croatian Science Foundation under the project number IP-201409-9541. Last but not least, we thank Julie ROBSON for the English corrections.

\section{REFERENCES}

BANNER, F.T. \& DESAI, D. (1985): The genus Clavulinoides Cushman emended and the new Cretaceous genus Clavulinopsis.- Journal of Foraminiferal Research, 15, 79-90. doi: 10.2113/gsjfr.15.2.79

BANNER, F.T., SIMMONS, M.D. \& WHITTAKER, J.E. (1991): The Mesozoic Chrysalidinidae (Foraminifera, Textulariacea) of the Middle East: the Redmond (Aramco) taxa and their relatives.- Bulletin of the British Museum (Natural History) Geology, 47/2, 101-152.

BERTHELIN, G. (1880): Mémoire sur les Foraminifères fossils de l'Etage Albien de Moncley (Doubs).-- Mémoires de la Société Géologique de France, ser. 3, 1 (5), 1-84.

CHECCONI, A., RETTORI, R. \& SPALLUTO, L. (2008): Biostratigrapfia a foraminiferei del Cretaceo Superiore della succession di Parco Priore (Calcare di Altamura, Piattaforma Apula, Italia Meridionale).-Annali dell'Universita degli Studi di Ferrara Museologia Scientifica e Naturalistica, 4, 1-9. doi: 10.15160/1824-2707/4/1

CHERCHI, A., RADOIČIĆ, R., SCHROEDER, R., 1991. Neobalkhania bignoti n. gen., n. sp., grand Foraminifère du Maastrichtian supérieur du Sud-est de 1'Europe.Comptes Rendus de 1' Academie des Sciences, Série II, 313, 287-292.

CUSHMAN, J.A. (1911): A Monograph of the Foraminifera of the North Pacific Ocean. Part II - Textulariidae.- United States National Museum Bulletin, 71, 1-108. doi: 10.5479/si.03629236.71.2

CUSHMAN, J.A. (1927): An outline of a re-classification of the foraminifera.- Contributions from the Cushman Laboratory for Foraminiferal Research, 3, 1-105.

CUSHMAN, J.A. (1933): Some new foraminiferal genera-- Contributions from the Cushman Laboratory for Foraminiferal Research, 9, 32-38.

CUSHMAN, J A. (1935): Fourteen new species of Foraminifera.- Smithonian Miscellaneous Collections 91 (21), 181, 1-9. doi: 10088/23898/SMC_91

CUSHMAN, J.A. (1936): New genera and species of the families Verneuilinidae and Valvulinidae and of the subfamily Virgulininae.- Special Publications Cushman Laboratory for Foraminiferal Research, 6, 1-71.

CVETKO, B., GUŠIĆ, I., SCHROEDER, R. (1997): Reticulinella fleuryi n. sp. (Foraminiferida) from the Upper Cretaceous (Upper Santonian-Middle Campanian of the Island of Brač, Croatia.- Revue de Micropaléontologie, 40/2, 131-139. doi:10.1016/S0035-1598(97)90530-4

CVETKO TEŠOVIĆ, B., GUŠIĆ, B., JELASKA, V., BUCKOVIĆ, D. (2001): Stratigraphy and microfacies of the Upper Cretaceous Pučišća Formation, Island of Brač, Croatia.- Cretaceous Research, 22, 591-613. doi: 10.1006/cres.2001.0279

DAVEY, S.D. \& JENKYNS, H.C. (1999): Carbon-isotope stratigraphy of shallow-water limestones and implications for the timing of Late Cretaceous sea-level rise and anoxic events (Cenomanian-Turonian of the peri-Adriatic carbonate platform, Croatia).- Eclogae Geologicae Helvetiae, 92, 163-170. doi: org/10.5169/seals-168658

DE CASTRO, P. (1974): Su alcune nuove miliolidi del Senoniano del Mediterraneo.- VI Instituto di Paleontologia dell'Università di Napoli Pubblicazione, 54, 1-19.

DE CASTRO, P., DROBNE, K. \& GUŠIĆ, I. (1994): Fleuryana adriatica n. gen., n. sp. (Foraminiferida) from the uppermost Maastrichtian of the Brač Island (Croatia) and some other localities on the Adriatic Carbonate Platform.- Razprave IV. Razreda SAZU, 35/8, 129-149.

D'ORBIGNY, A. (1826): Tableau méthodique de la classe des Céphalopodes.-Annales des Sciences Naturelles, 7, 245-314.

FRIJIA, G., PARENTE, M., DI LUCIA, M. \& MUTTI, M. (2015): Carbon and Strontium isotope stratigraphy of the Late Cretaceous (Cenomanian-Campanian) shallow-water carbonates of southern Italy: chronostratigraphic calibration of larger 
foraminifera biostratigraphy.- Cretaceous Research, 53, 110-139. doi: 10.1016/j. cretres.2014.11.002

GALLOWAY, J.J. (1933): A manual of Foraminifera. Bloomington, Principia Press.

GUŠIĆ, I. \& JELASKA, V. (1990): Upper Cretaceous stratigraphy of the Island of Brač.Djela Jugoslavenska Akademija Znanosti i Umjetnosti Zagreb, 69, 1-160.

HOTTINGER, L. (2006): Illustrated glossary of terms used in foraminiferal research. Carnets de Géologie.- Notebooks on Geology Memoires 2006/02. doi: CG2006 M02

HOTTINGER, L., HALICZ, E. \& REISS, Z. (1990): Partitions and fistulose chambers in Textulariina.-In: HEMLEBEN, C., KAMINSKI, M.A., KUHNT, W. \& SCOTT, D.B. (eds.): Paleoecology, biostratigraphy, paleoceanography and taxonomy of agglutinated foraminifera. Dordrecht, Kluwer Academic Publisher, 37-49. doi: 10.1007/978-94-011-3350-0

JELASKA, V. (2002): Carbonate Platforms of the External Dinarides.- In: VLAHOVIĆ, I. \& TIŠLJAR, J. (eds.): Evolution of Depositional Environments from the Palaeozoic to the Quaternary in the Karst Dinarides and Pannonian Basin.- 22nd IAS Meeting of Sedimentology, Opatija, Field Trip Guidebook, 67-71.

JENKYNS, H.C. (1991): Impact of Cretaceous sea level rise and anoxic events on the Mesozoic carbonate platform of Yugoslavia.-American Association of Petroleum Geologists, Bulletin, 75/6, 1007-1017.

KAMINSKI, M.A., CETEAN, C.G. \& TYSZKA, J. (2011): Nomenclature to describe the transition from multiserial to uniserial chamber arrangement in benthic foraminifera.- Journal of Micropalaeontology, 30, 7-10. doi: 10.1144/0262-821X10-016

KAMINSKI, M.A., CETEAN, C.G. \& NEAGU, T. (2010): Rectogerochammina eugubina nov. gen., nov. sp., a new agglutinated foraminifer from the Upper Cretaceous of Gubbio, Italy.- Revue de Micropaléontologie, 53, 121-124. doi:10.1016/ jraminifera

KORBAR, T. (2003): Stratigrafija, taksonomija i paleoekologija radiolitida gornje krede Jadranske karbonatne platforme (Stratigraphy, Taxonomy and Palaeoecology of Upper Cretaceous Radiolitidae of the Adriatic Carbonate Platform).-PhD Thesis, University of Zagreb, Croatia, 242 p. (in Croatian with English summary, unpublished).

KORBAR, T., GLUMAC, B., CVETKO TEŠOVIĆ, B., CADIEUX, S. B. (2012): Response of a carbonate platform to the Cenomanian-Turonian drowning and $\mathrm{OAE}$ 2: a case study from the Adriatic Platform (Dalmatia, Croatia).- Journal of Sedimentary Research, 82, 163-176. doi:10.2110/jsr.2012/17

KORBAR, T. \& HUSINEC, A. (2003): Biostratigraphy of Turonian to (?)Coniacian platform carbonates: A case study from the Island of Cres (Northern Adriatic, Croatia).- Geologia Croatica, 56, 173-185. doi: 10.4154/GC.2003.11

LOEBLICH, A.R., JR. \& TAPPAN, H. (1985): Some new and redefined genera and families of agglutinated foraminifera II.- Journal of Foraminiferal Research, 15/3, 175-217. doi: $10.2113 / \mathrm{gsjfr} .15 .3 .175$

LOEBLICH, A.R., JR. \& TAPPAN, H. (1987): Foraminiferal genera and their classification. - 2 volumes, 1-970, (Van Nostrand Reinhold) New York. doi: 10.1007/978$1-4899-5760-3$

LUPERTO SINNI, E. (1976): Microfossili senoniani delle Murge.- Rivista Italiana di Paleontologia e Stratigrafia, 82/2, 293-416.

LUPERTO SINNI, E. (1979): Praechrysalidina infracretacea n. gen., n. sp. (Foraminiferida) del Cretaceo inferiore delle Murge Baresi-- Studi geologici e morfologici sulla Regione Pugliese, 5, 1-16.
LUPERTO SINNI, E. (1985): Praechrysalidina infracretacea LUPERTO SINNI, 1979. - In: SCHROEDER, R. \& NEUMANN, M. (coords.), Les grand foraminifères du Crétacé Moyen de la région Méditerranénne.- Géobios Mémoire spécial, 7, 22.

NEAGU, T. (1997): Lower Cretaceous agglutinated foraminifera from southern Dobrogea, omania. Part 1, Verneuilinacea, Ataxophragmiacea.-Annales Societatis Geologorum Poloniae, 67, 307-323.

PAMIĆ, J., GUŠIĆ, I. \& JELASKA, V. (1998): Geodynamic evolution of the Central Dinarides.- Tectonophysics, 297, 251-268. doi: 10.1016/S0040-1951(98)00171-1

PEJOVIĆ, D. \& RADOIČIĆ, R. (1987): Contribution to the study of Upper Cretaceous stratigraphy of Brač - Adriatic Carbonate Platform.- Geologija, 28/29, 121-150 (In Serbian, English summary).

PILLER, W.E. (1990): Wall structures of palaeotextulariid foraminifers and discussion of microgranular test walls.- Paleoecology, Biostratigraphy and Taxonomy of agglutinated Foraminifera. NATO ASI Series, 327, 25-35. doi: 10.1007/978-94-0113350-0 4

POLŠAK, A., BAUER, V. \& SLIŠKOVIĆ, T. (1982): Stratigraphie du Crétacé supérieur de la plate-forme carbonatée dans les Dinarides externs.- Cretaceous Research, 3, 125-133. doi: 10.1016/0195-6671(82)90013-1

RIGAUD, S., VACHARD, D. \& MARTINI, R. (2015): Agglutinated versus microgranular foraminifers: end of a paradigm?- Journal of Systematic Palaeontology, 13/2, 75-95. doi:10.1080/14772019.2013.863232

SCHLAGINTWEIT, F., HUSINEC, A. \& JEŽ, J. (2014): Siphodinarella costata $n$. gen., n. sp., a new benthic foraminifer from the Upper Cretaceous (Late Turonian-Santonian) of the Karst Dinarides (Slovenia, Croatia).- Facies, 60, 133-145. doi: 10.1007/s10347-013-0365-1

SCHWAGER, C. (1877): Quadro del proposto sistema di classificazione dei foraminiferi con guscio.- Bolletino del R. Comitato Geologico d'Italia, 8, 18-27.

STEUBER, T., KORBAR, T., JELASKA, V. \& GUŠÍĆ, I. (2005): Strontium-isotope stratigraphy of Upper Cretaceous platform carbonates of the island of Brač (Adriatic Sea, Croatia): implications for global correlation of platform evolution and biostratigraphy.-Cretaceous Research, 26, 741-756. doi: 10.1016/j.cretres.2005.04.004

TORRE, M. (1966): Alcuni foraminiferi del Cretacico superiore della Penisola Sorrentina.- Bolletino della Società dei Naturalisti in Napoli, 75, 409-431.

TYSZKA, J. \& THIES, A. (2001): Spiroplectinata, key benthic foraminifera genus for palaeoceanographic reconstructions of the Albian Lower Saxony Basin.- Palaeogeography, Palaeoclimatology, Palaeoecolgy, 174, 199-220. doi: 10.1016/S00310182(01)00294-2

VACHARD, D., MUNNECKE, A. \& SERVAIS, T. (2004): New SEM observations of keriothecal walls: implications for the evolution of the Fusulinida.- Journal of Foraminiferal Research, 34/3, 232-242. doi: 10.2113/34.3.232

VELIĆ, I., (2007): Stratigraphy and palaeobiogeography of Mesozoic benthic foraminifera of the Karst Dinarides (SE Europe).- Geologia Croatica, 60, 1-113. doi: $10.4154 /$ GC.2007.01a

VLAHOVIĆ, I., TIŠLJAR, J., VELIĆ, I. \& MATIČEC, D. (2005): Evolution of the Adriatic Carbonate Platform: Palaeogeography, main events and depositional dynamics.- Palaeogeography, Palaeoclimatology, Palaeoecology, 220/3-4, 333-360. doi: 10.1016/j.palaeo.2005.01.011

WEIDICH, K.-F. (1988): On the variability of some Recent and fossil „Clavulina” species (Foraminifera). Abhandlungen der Geologischen Bundesanstalt, 41, 337-354. 